\title{
Matrix Metalloproteinase-9 in the Ventricular Cerebrospinal Fluid Correlated with the Prognosis of Traumatic Brain Injury
}

\author{
Travmatik Beyin Hasarmm Prognozuyla Ventriküler Beyin Omurilik \\ Stvisında Matriks Metalloproteinaz-9 Korelasyonu
}

\author{
Chun-Lin LIU1, Chun-Chang CHEN ${ }^{1,2}$, Han-Chung LEE ${ }^{1,2}$, Der-Yang CHO ${ }^{1,2}$ \\ ${ }^{1}$ China Medical University, Graduate Institute of Clinical Medical Science, Taichung, 40402, Taiwan \\ ${ }^{2}$ China Medical University Hospital, Department of Neurosurgery, Taichung, 40402, Taiwan
}

Corresponding Author: Chun-Lin LIU / E-mail: chunlin_lliu@yeah.net, chunlin2539@gmail.com

\begin{abstract}
AIM: Matrix metalloproteinase 9 (MMP-9) has been shown to be a potential biomarker for outcome prediction after neuron damage. This study investigated whether MMP-9 could be used for outcome prediction after traumatic brain injury (TBI).

MATERIAL and METHODS: For the TBI group, cerebrospinal fluid (CSF) was collected at different days after surgery from 6 head injury patients who had received surgical intervention with external ventricular drainage insertion. CSF collected from non-TBI patients $(\mathrm{N}=85)$ diagnosed with isolated hydrocephalus by a ventricular puncture during a ventriculo-peritoneal shunt surgery was used as control.

RESULTS: The mean concentration of MMP-9 in the CSF of 85 non-TBI patients was determined to be $1.172 \pm 0.859 \mathrm{ng} / \mathrm{mL}$. We found that the CSF MMP-9 concentration from TBI patients was elevated immediately after head injury with a median of $1.926 \mathrm{ng} / \mathrm{mL}$ (range, 0.673 to 24.990 ). Despite an early increase in the concentration of MMP-9, levels decreased within $72 \mathrm{hrs}$ and nearly reached the normal range. Nevertheless, the concentration of MMP-9 was negatively correlated with the Glasgow Coma Scale $(\gamma=-0.337, p=0.013)$.
\end{abstract}

CONCLUSION: MMP-9 concentration in the CSF of TBI patients correlated with neurological outcome and may represent an early indicator for the prognosis of this condition.

KEYWORDS: Cerebrospinal fluid, Biomarker, Matrix metalloproteinase-9, Traumatic brain injury, Glasgow Coma Scale

öz

AMAÇ: Matriks metalloproteinaz 9'un (MMP-9) nöron hasarından sonra sonuçların tahmin edilmesinde olası bir biyobelirteç olduğu gösterilmiştir. Bu çalışma, MMP-9'un travmatik beyin hasarından sonra sonucu öngörmek için kullanılıp, kullanılamayacağını incelemiştir.

YÖNTEM ve GEREÇLER: Travmatik beyin hasarı grubunda eksternal ventriküler drenaj yerleştirilmesiyle cerrahi girişim yapılmış 6 kafa travması hastasında cerrahi sonrasında farklı günlerde beyin omurilik sıvısı (BOS) toplanmıştır. Kontrol olarak bir ventriküloperitoneal şant cerrahisi sırasında ventriküler ponksiyon ile izole hidrosefali tanısı konmuş, travmatik beyin hasarı olmayan hastalardan BOS toplanmıştır ( $\mathrm{N}=85$ ).

BULGULAR: Travmatik beyin hasarı olmayan 85 hastanın BOS'unda ortalama MMP-9 konsantrasyonunun 1,172 $\pm 0,859 \mathrm{ng} / \mathrm{mL}$ olduğu bulunmuştur. Travmatik beyin hasarı hastalarında BOS MMP-9 konsantrasyonunun kafa travmasından hemen sonra medyan 1,926 $\mathrm{ng} / \mathrm{mL}$ (aralık, 0,673 - 24,990) değeriyle yükseldiğini bulduk. MMP-9 konsantrasyonunda erken bir artışa rağmen seviyeler 72 saat içinde azaldı ve hemen hemen normal aralığa döndü. Yine de MMP-9 konsantrasyonu Glasgow Koma Skalası ile negatif korelasyon gösterdi $(\gamma=-0,337, p=$ 0,013).

SONUÇ: MMP-9 konsantrasyonu travmatik beyin hasarlı hastaların BOS'unda nörolojik sonuçla korelasyon gösterdi ve böylece prognoz için erken bir gösterge olabileceği düşünüldü.

ANAHTAR SÖZCÜKLER: Beyin omurilik sıvısı, Biyobelirteç, Matriks metalloproteinaz-9, Travmatik beyin hasarı, Glasgow Koma Skalası

\section{INTRODUCTION}

Traumatic brain injury (TBI) is a major cause of morbidity and mortality throughout the world, and each year about $2,000,000$ hospital admissions in the European Union and USA alone are due to TBI (7). Despite there being a number of biomarkers that have been shown to correlate with injury magnitude and survivability $(5,13)$, there are few reliable methods to predict the clinical outcomes for TBI patients; therefore, there is a desperate need to identify more specific and sensitive biomarkers to serve as parameters for TBI management and prognosis.

Matrix metalloproteinases (MMPs) are a family of zinc-binding proteolytic enzymes that normally remodel the extracellular matrix (ECM). MMP-2 and MMP-9 specifically degrades type IV collagen, laminin, and fibronectin, which are the major components of the basal lamina around cerebral blood 
vessels (22). Numerous studies from both human and animal models of stroke have demonstrated that activation of MMP-9 contributes to the proteolytic breakdown of the blood-brainbarrier (BBB) $(3,16,29)$ and BBB disruption may also play an important role in the secondary injury associated with TBI (25). Although the mechanisms underlying BBB disruption are influenced by many factors, numerous studies have focused on the role of MMP-9 as a major contributor to BBB disruption (2). Moreover, MMP-9 levels can be influenced by secondary brain injuries such as inflammation in a tissue-specific manner (4), and MMP-9 has been considered a biomarker for the severity and functional outcome after stroke (19). Nevertheless, most of these studies have evaluated MMP-9 levels in the serum and there is no established baseline concentration of MMP-9 in the cerebro-spinal fluid (CSF) that has been reported.

We hypothesize that expression levels of CSF MMP-9 can be used as a biomarker to predict brain injury status. The objective of this study is to compare the expression levels of MMP-9 in the CSF from either TBI patients or non-TBI patients with hydrocephalus, the later of which would establish a baseline reference range of MMP-9 concentrations in the CSF. In addition, we would explore whether continuous monitoring of the MMP-9 concentration in the CSF of patients with cerebral trauma could predict the prognosis of these patients. The results of this study demonstrated that the MMP-9 concentration in the CSF of TBI patients closely correlated with neurological outcome and may represent an early indicator for the prognosis of this condition.

\section{PATIENTS and METHODS}

Subjects in the non-TBI group (as control) and TBI group were recruited from March 1, 2009 to January 31, 2010 (a total of 11 months) and CSF samples were collected during this time period. Because the collection of human CSF is an invasive procedure, the collection of spinal cord fluid from a large healthy population is difficult and also violates ethical principles. Therefore, the control group was composed of patients diagnosed with isolated hydrocephalus (patients with malignant tumors and infections were excluded) and were conscious when the CSF was collected during the ventricular drainage tube placement. In the TBI group, patients with cerebral trauma who had received surgical intervention and external ventricular drainage tube placement were recruited and CSF was monitored continuously.

In the control group (hydrocephalus alone), CSF (5 ml) was collected during the ventricular drainage tube placement and immediately stored at $-80^{\circ} \mathrm{C}$. In the experimental group (cerebral trauma), CSF $(5 \mathrm{ml}$ ) was collected during the ventricular drainage tube placement and immediately stored at $-80^{\circ} \mathrm{C}$. Except for the day of surgery, CSF (5 ml) was collected from the drainage tube daily after surgery and immediately stored at $-80^{\circ} \mathrm{C}$. CSF was collected approximately 10 times in each patient. During the collection of CSF, the coma index and intracerebral pressure were also determined by way of real-time intraparenchymal ICP monitoring just before CSF sampling for further analysis. The ELISA test was employed to detect the MMP concentration in the CSF with a commercial kit (Quantikine ${ }^{\circledR}$, R\&D Systems, Inc., Minneapolis, MN, USA).

The entire protocol was approved by the Institutional Review Board of China Medical University before the study was initiated. All of the procedures were explained to the patients and/or their relatives and informed consent was obtained.

\section{Statistical Analysis}

The change in the concentration of MMP-9 in TBI patients who had received surgical intervention with external ventricular drainage insertion over the course of 10 days was determined by using an ANOVA with repeated measurements. Gender is presented as a percentage, while age and cerebrospinal fluid MMP-9 concentration are presented as mean \pm standard deviation. Pearson's correlation coefficient was used to test if the CSF concentrations of MMP-9 correlated with age or gender in patients with hydrocephalus. In addition, Spearman's correlation coefficient was used to test if CSF concentrations of MMP-9 correlated with intracranial pressure or Glasgow Coma Scale (GCS) in patients with TBI. All statistical assessments were two-sided and evaluated at the 0.05 level of significance. Statistical analyses were performed using SPSS 15.0 statistics software (SPSS Inc, Chicago, IL, USA).

\section{RESULTS}

A total of 105 patients with hydrocephalus were enrolled in the control group; however, hydrocephalus patients with malignant tumors, infections, central bleeding or subarachnoid hemorrhage were excluded. A total of 85 CSF samples were obtained from patients undergoing ventriculoperitoneal shunt implantation. These patients included 51 men and 34 women with a mean age of $57.98 \pm 20.79$ years (range, 1-92 years). The average CSF MMP-9 concentration in patients with hydrocephalus was $1.172 \pm 0.859 \mathrm{ng} / \mathrm{mL}$ (Table I). Moreover, the CSF concentration of MMP-9 in the patients with hydrocephalus was not related to age $(\gamma=$ $-0.113, p=0.302)$ or gender $(\gamma=0.082, p=0.453)$. We used this average CSF MMP-9 concentration $(1.172 \pm 0.859 \mathrm{ng} / \mathrm{mL})$ from hydrocephalus patients as the baseline control data.

The TBI group consisted of 8 head injury patients who had received surgical intervention with external ventricular drainage insertion. There were 7 men and 1 woman with a mean age of $58.63 \pm 19.04$ years (range, 31-81 years). Of these 8 patients, only 6 survivors ( 5 males $/ 1$ female) could

Table I: Age Range and Sex Distribution of Patients with Hydrocephalus $(\mathrm{n}=85)$ and the Average CSF MMP-9 Concentration

\begin{tabular}{|l|c|}
\hline Characteristics & $\mathbf{N}=85$ \\
\hline Age (years) & $57.98 \pm 20.79$ (range:1-92) \\
\hline \begin{tabular}{l} 
Gender, $\mathrm{n}(\%)$ \\
\multicolumn{1}{c|}{ Male }
\end{tabular} & $51(60.0)$ \\
\multicolumn{1}{c|}{ Female } & $34(40.0)$ \\
\hline $\begin{array}{l}\text { CSF MMP-9 concentration } \\
\text { (ng/mL) }\end{array}$ & $1.172 \pm 0.859$ \\
(range: $0.485-4.000)$
\end{tabular}


be used for the final analyses (Table II), in which two patients were diagnosed as traumatic intracerebral hemorrhage, two as diffuse axonal injuries, one as traumatic subarachnoid hemorrhage and one as traumatic subdural hematomas. Although the MMP-9 concentration was elevated in TBI patients with a median of $1.926 \mathrm{ng} / \mathrm{mL}$ (ranging, 0.673 to 24.990), there was no trend in MMP-9 levels over the 10 days following the head injury $(p=0.750)$. Furthermore, the concentration of MMP-9 decreased within 3 days after the injury and nearly reached the normal range (Figure 1). The correlation between CSF concentrations of MMP-9 and intracranial pressure or GCS in TBI patients are represented in Figure $2(A, B)$. The concentration of MMP-9 was negatively correlated with GCS $(\gamma=-0.337, p=0.013)$. However, there was no significant correlation between the concentration of MMP-9 and intracranial pressure $(p=0.140)$.

Among the TBI subjects, two patients died. CSF was collected once in one patient (patient 7) who died within $24 \mathrm{hr}$.
The MMP-9 level was $25.84 \mathrm{ng} / \mathrm{mL}$ in this patient, which was significantly higher than that in the control group $(1.172 \pm 0.859 \mathrm{ng} / \mathrm{mL}$ ). The other patient (patient 8) developed a delayed cerebral hemorrhage and died on the third day. The MMP-9 levels for this patient were $3.27 \mathrm{ng} / \mathrm{mL}, 18.18 \mathrm{ng} /$ $\mathrm{mL}, 32.70 \mathrm{ng} / \mathrm{mL}$, and $20.35 \mathrm{ng} / \mathrm{mL}$ for days 0-3, respectively, which showed an increasing trend. Among the 6 patients that survived, one patient (patient 5) had an extremely high MMP-9 level $(24.99 \mathrm{ng} / \mathrm{mL})$ during the surgery. Although the MMP-9 level reduced to nearly normal levels within 3 days after surgery in this patient $(2.70 \mathrm{ng} / \mathrm{mL})$, he/she was still in a state of severe coma $(\mathrm{GCS}<8)$. These findings imply that MMP9 expression is closely related to the degree of initial injury to the central nervous system.

\section{DISCUSSION}

This study examined the hypothesis that the concentration of MMP-9 in the cerebrospinal fluid of a TBI patient is correlated

Table II: The Demographics of the 6 Survivors

\begin{tabular}{|c|c|c|l|c|c|c|}
\hline & & & \multicolumn{3}{|c|}{ Day 1 measurement } \\
\hline 1 & $\begin{array}{c}\text { Age } \\
\text { (years) }\end{array}$ & Gender & Diagnosis & $\begin{array}{c}\text { MMP-9 } \\
\text { (ng/mL) }\end{array}$ & $\begin{array}{c}\text { ICP } \\
\text { (mmHg) }\end{array}$ \\
\hline 2 & 51 & Male & Traumatic intracerebral hemorrhage & 0.673 & 18 & 11 \\
\hline 3 & 76 & Male & Diffuse axonal injuries & 2.000 & 12 & 6 \\
\hline 4 & 41 & Male & Traumatic subdural hematomas & 1.851 & 2 & 6 \\
\hline 5 & 31 & Male & Diffuse axonal injuries & 1.772 & 6 \\
\hline 6 & 60 & Male & Traumatic intracerebral hemorrhage & 24.990 & 25 & 9 \\
\hline
\end{tabular}

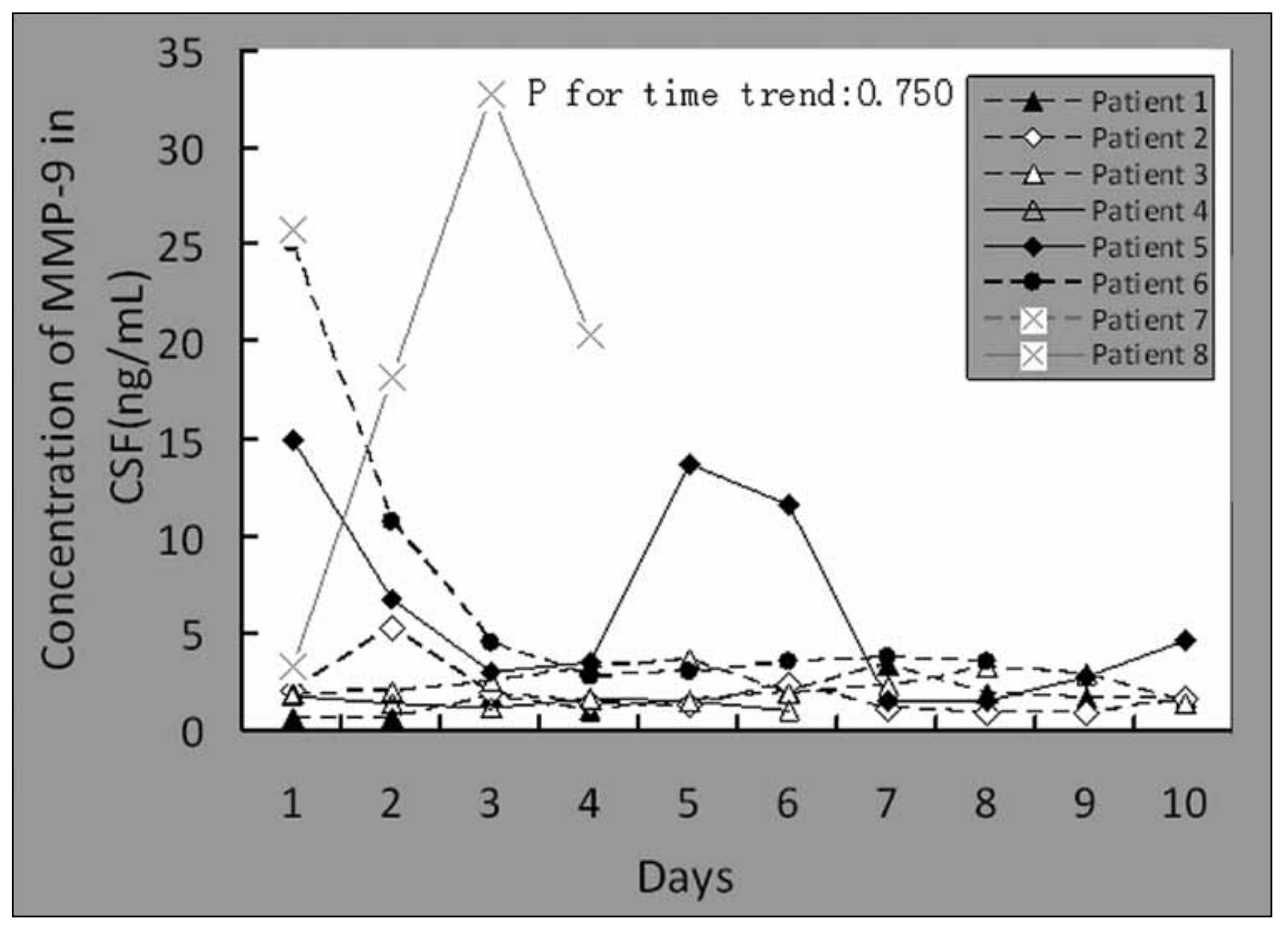

Figure 1: The average concentration of MMP-9 in TBI patients. MMP-9 concentration ( $\mathrm{ng} / \mathrm{mL}$ ) was calculated by an ELISA method from CSF (5 $\mathrm{mL}$ ) collected via an external ventricular drainage tube immediately following injury (Day 1). CSF was collected daily for up to 10 days following injury ( $\mathrm{n}=6$ patients, Patient 7 and 8 died early). 

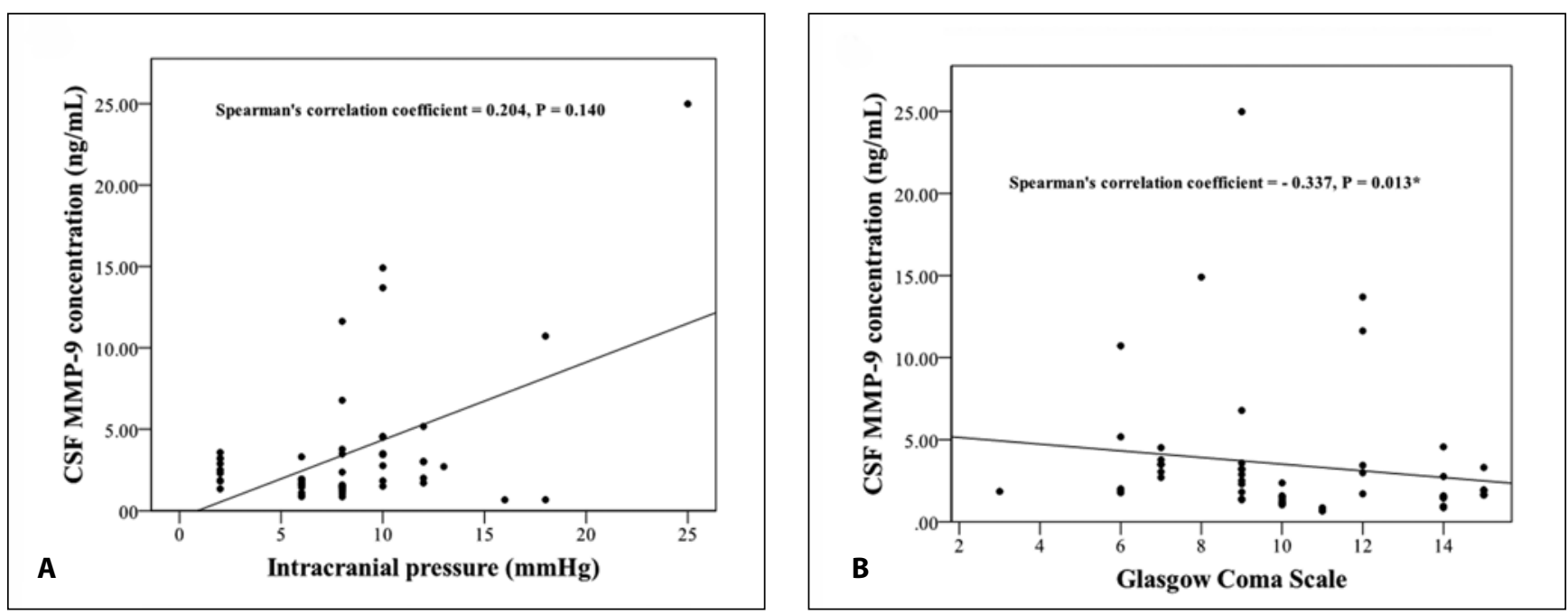

Figure 2: Correlation between CSF concentrations of MMP-9 and intracranial pressure or Glasgow Coma Scale in TBI patients. MMP9 concentration $(\mathrm{ng} / \mathrm{mL})$ was correlated with intracranial pressure (A) and Glasgow Coma Scale (B) using Spearman's correlation coefficient.

with outcome or prognosis. To begin to examine the prognostic value of MMP-9 in the CSF, the baseline average concentration of MMP-9 in the CSF among non-TBI control patients was determined. Because of ethical reasons and the invasive nature of CSF collection, the control data were obtained from 85 hydrocephalus patients (after excluding those with malignant tumors and infections), and these results demonstrated that the average MMP-9 concentration was approximately $1.172 \mathrm{ng} / \mathrm{mL}$. Importantly, a reliable baseline value such as this has not been previously reported in the literature, and it was necessary in order to allowed us to establish a reference point for the next stage of this study. Namely, the concentration of MMP-9 in the CSF from 8 TBI patients at different time points was examined to see if there was a correlation between the MMP-9 concentration and patient outcome. There was a increase of CSF MMP-9 in TBI patients immediately following their injury, and this increase negatively correlated with GCS. These findings suggest that the higher the CSF MMP-9 concentration immediately following an injury, the more the severe the TBI damage.

Currently, the prognosis of patients with cerebral injury including cerebral stroke and cerebral trauma is difficult to predict. Numerous approaches have been used in the prognosis of TBI patients such as imaging examinations with computerized tomography (CT) and magnetic resonance imaging (MRI), neurological scales including Glasgow coma scale and Barthal index, as well as the monitoring of intracerebral pressure/cerebral perfusion pressure as indirect strategies (24); however, the prognostic efficacy of these tools for the prediction of $\mathrm{TBI}$ patient outcome is still relatively poor (18). In addition to these prognostic tools, numerous biochemical markers have been used to predict the prognosis of patients with cerebral injury, including alpha-II spectrin $(14,17)$, tissue type plasminogen activator (1), Bcl-2 and cytochrome C (32), as well as S100B in the serum (23) and CSF
(27). Following brain injury, S100B passage from the CSF to the blood was significantly impaired, and higher S100B serum/ CSF ratios were associated with an improved neurological recovery (11). Overall, the majority of these studies stress the importance of examining the CSF levels of a biomarker for brain injury.

In addition to these aforementioned biomarkers, MMP-9 has been shown to be a biomarker for brain injury after stroke (15, 19), although most of the previous studies have examined serum levels of MMP-9. Nevertheless, there is a great deal of supporting evidence that MMP-9 should also be increased in the central nervous system. Notably, MMP-9 is one of the members of the MMP family that is mainly distributed in the central nervous system, especially in the glial cells of cerebral interstitial tissues (8). Moreover, MMP-9 has been shown to increase in the brain after stroke in both human (21) and in rodent models (20). In a mouse model of intracerebral hemorrhage, MMP-9 was upregulated in neurons and reactive astrocytes surrounding the hematoma (30). Thus, these studies demonstrate that MMP-9 serves a critical role in brain tissue pathology during injury, although the investigation of human brain tissue to elucidate biomarker changes after brain injury is inapplicable in most clinical settings. In contrast, serum is easy to collect after brain injury, although the findings based on serum measurements are largely indirect and typically do not influence clinical practice. Thus, the present study aimed to investigate the changes in CSF proteins as the next best direct measure of brain changes after TBI, which were then used to predict the prognosis of cerebral injury.

CSF is mainly collected by lumbar puncture and ventricular drainage. Both methods are invasive but ventricular drainage is the preferred method to collect CSF, considering the safety of patients and the amount and quality of the samples (26). External ventricular drainage is also beneficial for the 
monitoring of intracranial pressure although it is more invasive than venipuncture for blood collection. Moreover, continuous monitoring of the CSF can help avoid and treat common complications such as intracranial pressure increases (6). Thus, the collection of CSF by ventricular drainage was not only helpful for monitoring the reported changes in MMP-9, this method was more safe and direct than blood collection for MMP-9 detection. Interestingly, our results did not show a correlation with MMP-9 levels and intracranial pressure. In fact, neurologic outcome is more precisely correlated to the maintenance of cerebral perfusion pressure but not ICP (10). This finding suggests that MMP-9 does not contributed to the mechanisms triggered by primary injury that lead to cerebral edema and the eventual rise in intracranial pressure (28).

In the experimental group, the MMP-9 level in the patients with traumatic brain injury was the highest on the day of injury and then decreased to nearly normal levels within 3 days. This is similar to the findings of Kolar et al. (12) in serum measurements who observed the highest level of MMP-9 $24 \mathrm{hrs}$ after injury and then a return to normal levels after 3 days. For TBI patients, MMP-9 concentration in CSF elevated more quickly than in serum. Thus, these findings suggest that MMP-9 can be applied as an early biomarker for brain injury. In contrast, if the MMP-9 concentration remained at a high level, the mortality was significantly increased. Specifically, in the patient that the MMP-9 concentration that remained high until the third day after $\mathrm{TBI}$, the prognosis was very poor. Although the case numbers were too few to draw a statistically satisfactory conclusion, these findings suggest that sustained increases in MMP-9 CSF levels are associated with a poor prognosis for patient outcome.

Recently, Vilalta and colleagues (31) observed significantly elevated levels of proMMP- 2 and -9 in the plasma and brain extracellular fluid of patients with moderate or severe TBI, which was the first clinical study to examine MMPs after TBI. In addition, the recent work of Grossetete et al. (9) also reported the use of MPP-2 and MMP-9 as putative biomarkers for TBI prognosis, whereby the MMP-9 baseline was also determined in hydrocephalus patients. Beyond these two papers, no other studies have reported an association between CSF MMP-9 concentrations and TBI prognosis. Moreover, the present study was able to obtain CSF samples from 105 hydrocephalus patients and established a reliable average MMP-9 concentration for future studies. This is unlike the study of Grossetete et al. (9) who claimed there was no detectable MMP-9 in the CSF from hydrocephalus patients after normalization. Thus, ours is the first report establishing this kind of data and is the only study that has confirmed the previous findings of Grossetete et al. (9).

There were some limitations of this study. First, the TBI patient sample size was small. Second, TBI patients could not acquire CSF before injury. Third, pro-MMP-9/MMP-9 ratio might be more precise to predict severity of TBI.

Taken together, there are three principal conclusions that can be drawn from this work: 1) the establishment of a reliable baseline CSF MMP-9 concentration among non-TBI patients; 2) an increase in the CSF MMP-9 concentration immediately after a TBI insult correlates with the severity of the TBI damage; 3) an increased CSF MMP-9 concentration 72 hrs post-TBI predicts a poor prognosis. Although our results need to be replicated in larger cohort studies, these findings suggest that CSF levels of MMP-9 can serve as a prognostic indicator for patient outcome following TBI.

\section{REFERENCES}

1. Armstead WM, Kiessling JW, Riley J, Cines DB, Higazi AA: tPA contributes to impaired NMDA cerebrovasodilation after traumatic brain injury through activation of JNK MAPK. Neurol Res 33:726-733, 2011

2. Barr TL, Latour LL, Lee KY, Schaewe TJ, Luby M, Chang GS, El-Zammar Z, Alam S, Hallenbeck JM, Kidwell CS, Warach S: Blood-brain barrier disruption in humans is independently associated with increased matrix metalloproteinase-9. Stroke 41:e123-e128, 2010

3. Batra A, Latour LL, Ruetzler CA, Hallenbeck JM, Spatz M, Warach $S$, Henning EC: Increased plasma and tissue MMP levels are associated with BCSFB and BBB disruption evident on post-contrast FLAIR after experimental stroke. J Cereb Blood Flow Metab 30:1188-1199, 2010

4. Candelario-Jalil E, Yang Y, Rosenberg GA: Diverse roles of matrix metalloproteinases and tissue inhibitors of metalloproteinases in neuroinflammation and cerebral ischemia. Neuroscience 158:983-994, 2009

5. Dash PK, Zhao J, Hergenroeder G, Moore AN: Biomarkers for the diagnosis, prognosis, and evaluation of treatment efficacy for traumatic brain injury. Neurotherapeutics 7:100-114, 2010

6. De Georgia MA, Deogaonkar A: Multimodal monitoring in the neurocritical intensive care unit. Neurologist 11:45-54, 2005

7. Ghajar J: Essay: The future of traumatic brain injury. Mt Sinai J Med 76:190-193, 2009

8. Gottschall PE, Deb S: Regulation of matrix metalloproteinase expressions in astrocytes, microglia and neurons. Neuroimmunomodulation 3:69-75, 1996

9. Grossetete M, Phelps J, Arko L, Yonas H, Rosenberg GA: Elevation of matrix metalloproteinases 3 and 9 in cerebrospinal fluid and blood in patients with severe traumatic brain injury. Neurosurgery 65:702-708, 2009

10. Juul N, Morris GF, Marshall SB, Marshall LF: Intracranial hypertension and cerebral perfusion pressure: Influence on neurological deterioration and outcome in severe head injury. The Executive Committee of the International Selfotel Trial. J Neurosurg 92:1-6, 2000

11. Kleindienst A, Meissner S, Eyupoglu IY, Parsch H, Schmidt C, Buchfelder M: Dynamics of S100B release into serum and cerebrospinal fluid following acute brain injury. Acta Neurochir Suppl 106:247-250, 2010

12. Kolar M, Pachl J, Tomasova H, Haninec P: Dymanics of matrixmetalloproteinase 9 after brain trauma--results of a pilot study. Acta Neurochir Suppl 102:373-376, 2008 
13. Kövesdi E, Lückl J, Bukovics P, Farkas O, Pál J, Czeiter E, Szellár D, Dóczi T, Komoly S, Büki A: Update on protein biomarkers in traumatic brain injury with emphasis on clinical use in adults and pediatrics. Acta Neurochir (Wien) 152:1-17, 2010

14. Mondello S, Robicsek SA, Gabrielli A, Brophy GM, Papa L, Tepas J, Robertson C, Buki A, Scharf D, Jixiang M, Akinyi L, Muller U, Wang KK, Hayes RL: all-spectrin breakdown products (SBDPs): Diagnosis and outcome in severe traumatic brain injury patients. J Neurotrauma 27:1203-1213, 2010

15. Montaner J, Molina CA, Monasterio J, Abilleira S, Arenillas JF, Ribó M, Quintana M, Alvarez-Sabín J: Matrix metalloproteinase-9 pretreatment level predicts intracranial hemorrhagic complications after thrombolysis in human stroke. Circulation 107:598-603, 2003

16. Pfefferkorn T, Rosenberg GA: Closure of the blood-brain barrier by matrix metalloproteinase inhibition reduces rtPA-mediated mortality in cerebral ischemia with delayed reperfusion. Stroke 34:2025-2030, 2003

17. Pineda JA, Lewis SB, Valadka AB, Papa L, Hannay HJ, Heaton SC, Demery JA, Liu MC, Aikman JM, Akle V, Brophy GM, Tepas JJ, Wang KK, Robertson CS, Hayes RL: Clinical significance of alphall-spectrin breakdown products in cerebrospinal fluid after severe traumatic brain injury. J Neurotrauma 24: 354-366, 2007

18. Raabe A, Grolms C, Keller M, Döhnert J, Sorge O, Seifert V: Correlation of computed tomography findings and serum brain damage markers following severe head injury. Acta Neurochir (Wien) 140:787-792, 1998

19. Ramos-Fernandez M, Bellolio MF, Stead LG: Matrix metalloproteinase-9 as a marker for acute ischemic stroke: A systematic review. J Stroke Cerebrovasc Dis 20:47-54, 2011

20. Romanic AM, White RF, Arleth AJ, Ohlstein EH, Barone FC: Matrix metalloproteinase expression increases after cerebral focal ischemia in rats: Inhibition of matrix metalloproteinase-9 reduces infarct size. Stroke 29:1020-1030, 1998

21. Rosell A, Ortega-Aznar A, Alvarez-Sabín J, Fernández-Cadenas I, Ribó M, Molina CA, Lo EH, Montaner J: Increased brain expression of matrix metalloproteinase- 9 after ischemic and hemorrhagic human stroke. Stroke 37:1399-1406, 2006
22. Rosenberg GA: Matrix metalloproteinases and their multiple roles in neurodegenerative diseases. Lancet Neurol 8: 205-216, 2009

23. Rothoerl RD, Woertgen C, Holzschuh M, Metz C, Brawanski A: S-100 serum levels after minor and major head injury. J Trauma 45:765-767, 1998

24. Saatman KE, Duhaime AC, Bullock R, Maas Al, Valadka A, Manley GT: Classification of traumatic brain injury for targeted therapies. J Neurotrauma 25:719-738, 2008

25. Shlosberg D, Benifla M, Kaufer D, Friedman A: Blood-brain barrier breakdown as a therapeutic target in traumatic brain injury. Nat Rev Neurol 6:393-403, 2010

26. Stangl AP, Meyer B, Zentner J, Schramm J: Continuous external CSF drainage--a perpetual problem in neurosurgery. Surg Neurol 50:77-82, 1998

27. Stein DM, Kufera JA, Lindell A, Murdock KR, Menaker J, Bochicchio GV, Aarabi B, Scalea TM: Association of CSF biomarkers and secondary insults following severe traumatic brain injury. Neurocrit Care 14:200-207, 2011

28. Steiner LA, Coles JP, Czosnyka M, Minhas PS, Fryer TD, Aigbirhio FI, Clark JC, Smielewski P, Chatfield DA, Donovan T, Pickard JD, Menon DK: Cerebrovascular pressure reactivity is related to global cerebral oxygen metabolism after head injury. J Neurol Neurosurg Psychiatry 74:765-770, 2003

29. Svedin P, Hagberg H, Sävman K, Zhu C, Mallard C: Matrix metalloproteinase- 9 gene knock-out protects the immature brain after cerebral hypoxia-ischemia. J Neurosci 27: 1511-1518, 2007

30. Tejima E, Zhao BQ, Tsuji K, Rosell A, van Leyen K, Gonzalez RG, Montaner J, Wang X, Lo EH: Astrocytic induction of matrix metalloproteinase- 9 and edema in brain hemorrhage. J Cereb Blood Flow Metab 27:460-468, 2006

31. Vilalta A, Sahuquillo J, Rosell A, Poca MA, Riveiro M, Montaner $\mathrm{J}$ : Moderate and severe traumatic brain injury induce early overexpression of systemic and brain gelatinases. Intensive Care Med 34:1384-1392, 2008

32. Wagner AK, Amin KB, Niyonkuru C, Postal BA, McCullough EH, Ozawa H, Dixon CE, Bayir H, Clark RS, Kochanek PM, Fabio A: CSF Bcl-2 and cytochrome $\mathrm{C}$ temporal profiles in outcome prediction for adults with severe TBI. J Cereb Blood Flow Metab 31:1886-1896, 2011 